\title{
A new Early Cretaceous relative of Gnetales: Siphonospermum simplex gen. et sp. nov. from the Yixian Formation of Northeast China
}

\author{
Catarina Rydin*1 and Else Marie Friis²
}

\begin{abstract}
Background: Knowledge on fossil and evolutionary history of the Gnetales has expanded rapidly; Ephedra and ephedroids as well as the Gnetum-Welwitschia clade are now well documented in the Early Cretaceous. However, hypotheses on evolutionary relationships among living and fossil species are hampered by restricted knowledge of morphological variation in living groups and recent studies indicate that gnetalean diversity and character evolution may be more complex than previously assumed and involve additional extinct groups (Bennettitales, Erdtmanithecales and unassigned fossil taxa).

Results: Here we describe a new fossil related to Gnetales, Siphonospermum simplex from the Early Cretaceous Yixian Formation, an impression/compression of a reproductive shoot. The slender main axis bears one pair of opposite and linear leaves with primary parallel venation. The reproductive units are ovoid, without supporting bracts and borne on one median and two lateral branches. The most conspicuous feature of the fossil is the long, thread-like micropylar tube formed by the integument. Each ovule is surrounded by two different layers representing one or two seed envelopes; an inner sclerenchymatous layer and an outer probably parenchymatous layer.

Conclusions: The vegetative and reproductive features of Siphonospermum simplex exclude a relationship to any other group than the Gnetales. A combination of opposite phyllotaxis, linear leaves and ovules surrounded by seed envelope(s) and with a long exposed micropylar tube are known only for extant and extinct Gnetales. Siphonospermum simplex constitutes a new lineage within the Gnetales. Its morphology cannot be directly linked to any previously known plant, but the organization of the reproductive units indicates that it belongs to the Gnetum-Welwitschia clade. Based on the absence of cone bracts and the inferred histology of the seed envelope(s) it could be related to Gnetum, however, there are also affinities with the ephedran lineage, some of which are likely plesiomorphic features, others perhaps not. Phylogeny and character evolution in the Bennettitales, Erdtmanithecales and Gnetales are currently only partly understood and under debate; the exact systematic position of Siphonospermum simplex, i.e., its position within the Gnetales, cannot be resolved with certainty.
\end{abstract}

\section{Background}

The Gnetales comprise about 65-75 species in three genera (Ephedra L., Gnetum L., Welwitschia Hook. f.) [1]. It has long been assumed that the extant species are relictual remnants of a former greater diversity [[2], and others], and the rapidly expanding documentation of gnetalean fossils from the Early Cretaceous supports this idea. The Gnetales are reported from the Early Creta-

* Correspondence: Catarina.Rydin@systbot.uzh.ch

1 University of Zürich, Institute of Systematic Botany, Zollikerstrasse 107, CH8008 Zürich, Switzerland

Full list of author information is available at the end of the article ceous of many parts of the world [3-16]. There are, in addition, fossils with a gnetalean affinity that are difficult to assign to any of the extant lineages [e.g., [17-20]] and a large diversity of pre-Cretaceous fossils, which have been discussed as potentially related to the Gnetales, but for which a precise systematic affinity remains to be established [e.g., [21,22]].

The members of the extant clade are characterized by several unique features [23-26], for example, decussate phyllotaxis, compound reproductive structures, polyplicate pollen and a single terminal unitegmic ovule with a resistant micropylar tube formed by the integument. The 
ovule is surrounded by structure(s) of bract origin (i.e., seed envelope[s]) and the micopylar tube reaches beyond the seed envelope and serves as the pollen receiving area [e.g., [26]]. Ephedra has retained many ancestral features, but can be defined by specialized pollen characters [27] and apical papillae on the seed envelope [28,29]. The sister group of Ephedra, the Gnetum-Welwitschia clade, is defined e.g., by the presence of an embryo feeder, higher order venation and many anatomical, histological and developmental details $[23,30]$. Assigning a fossil to either of the two major groups of the Gnetales is thus often straight forward due to the presence of these clear synapomorphies, but resolving higher level relationships among living and fossil taxa has proven difficult, partly due to restricted knowledge of phylogeny and morphological variation among living species. Further, it has lately been suggested that the Gnetales belong to a larger clade [the BEG-clade sensu Friis et al., see [31]], which also comprises the Bennettitales, the Erdtmanithecales and several unassigned fossil taxa $[14,18,31]$. The BEG hypothesis has been questioned [32]; interpretations of the integument in Bennettitales differ between authors, but nevertheless, evolutionary patterns in the Gnetales and potential stem lineages are obviously more complex than previously recognized.

In this study we add to the knowledge of gnetalean diversity in the Early Cretaceous. We describe and discuss an impression/compression fossil from the Liaoning province of north-eastern China collected in Early Cretaceous sediments of the Yixian Formation.

\section{Results}

The type material of Siphonospermum simplex comprises two impression/compression fossils of a female plant, part and counterpart, with remnants of oxidized organic material (Figure 1). Few anatomical details are preserved, but lignified tissues can be observed. The total preserved length is about $25 \mathrm{~mm}$. The branch bearing the cluster of ovules is about $0.5 \mathrm{~mm}$ thick and has one pair of opposite leaves. Leaves are linear, at least 10-13 $\mathrm{mm}$ long and 0.3$0.4 \mathrm{~mm}$ wide, and with remains of three primary veins. Three reproductive units are positioned terminally on one median and two lateral branches and are naked, without supporting bracts (Figure 1).

Reproductive units are about 8-9 mm long and 1.5-2 $\mathrm{mm}$ wide, narrowly ovoid with a rounded base and an extended acuminate apex (Figure 2a). Each ovule is surrounded by two distinct layers, which represent one or two seed envelopes (Figures 2b, Figure 3). The outermost layer is seen as an imprint in apical parts of the ovules. It is about $0.3-0.5 \mathrm{~mm}$ thick. The innermost layer appears massive with remnants of coaly matter. Numerous supportive strands form a pattern with dichotomies and

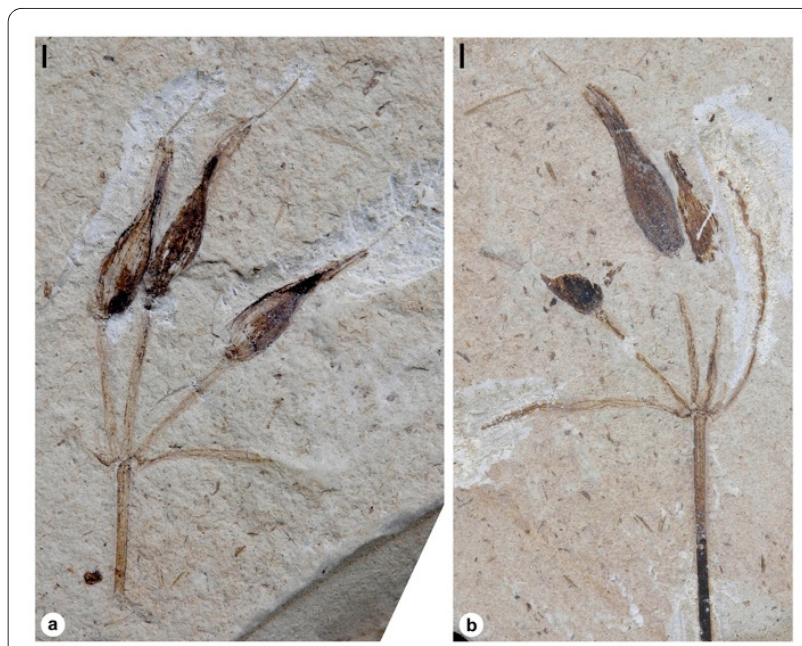

Figure 1 Siphonospermum simplex gen. et sp. nov. Overview of the holotype (part and counterpart): (a) specimen 9880A; (b) specimen 9880B. Scale bars: $1 \mathrm{~mm}$.

anastomoses (Figure 2a). No papillae are observed on the seed envelope lining the micropylar tube.

There is a long thread-like micropylar tube that extends well above the surrounding seed envelope(s). The micro-

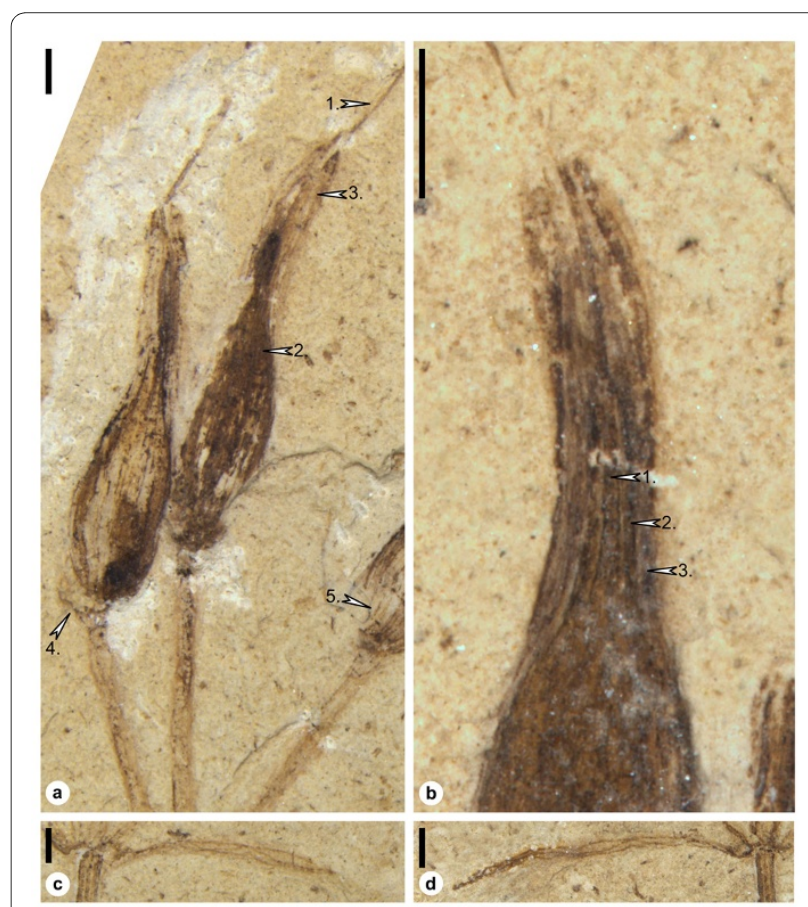

Figure 2 Siphonospermum simplex gen. et sp. nov. Details of $(a, c)$ specimen 9880A; (b, d): specimen 9880B. (a) Reproductive units of Siphonospermum simplex. (b) Close up of the reproductive unit seen in Figure $1 \mathrm{~b}$. (c-d) Node and linear leaf with parallel first order venation. Arrows 1: micropylar tube formed by the integument; 2: second (mostly sclerenchymatous) layer; 3 : third (probably mostly parenchymatous) layer; 4 : the ovule has been detached and slightly displaced; 5: supportive strands of the (inner) seed envelope. Scale bars: $1 \mathrm{~mm}$. 


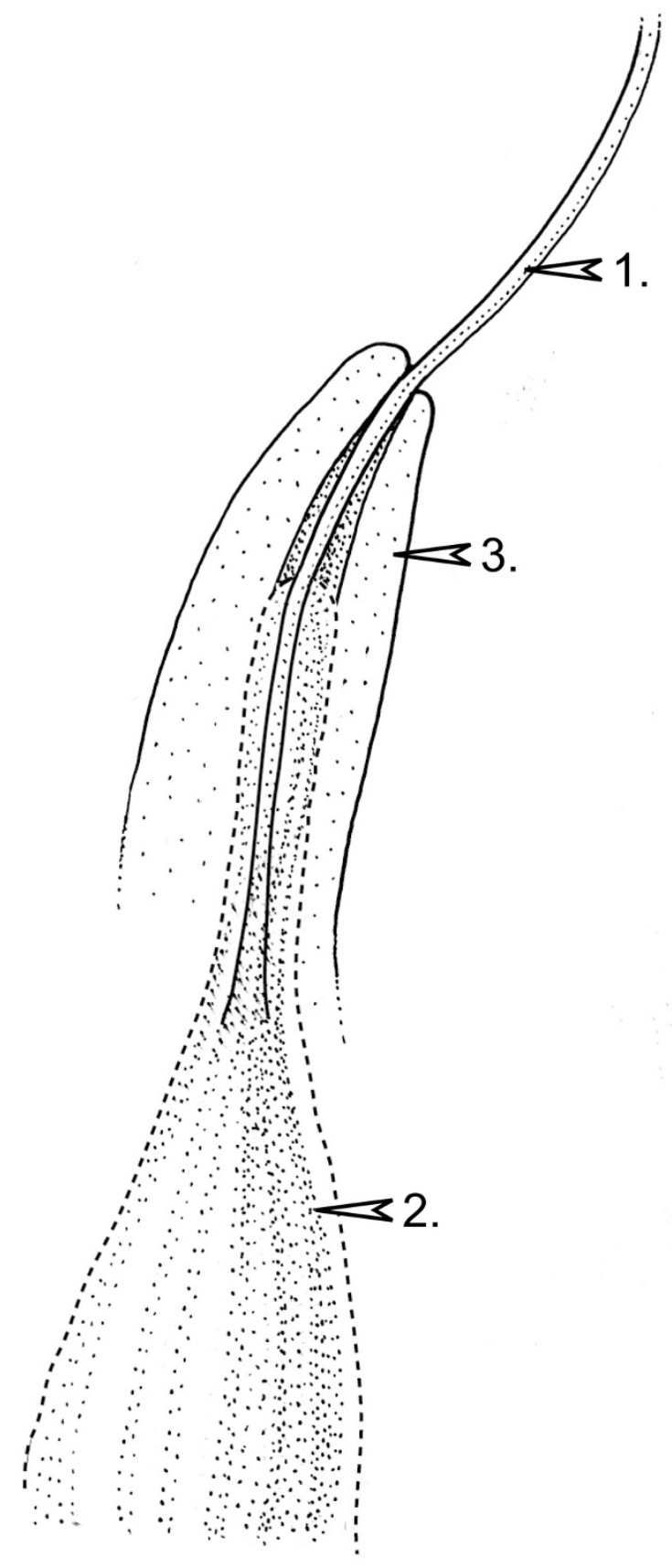

Figure 3 Reconstruction of Siphonospermum simplex. Reproductive unit; reconstruction of a longitudinal section. Arrows 1: micropylar tube, 2: second (mostly sclerenchymatous) layer, 3: third (probably mostly parenchymatous) layer. Uninterrupted lines indicate morphological surfaces. The dashed line indicates the boundary between the second (mostly sclerenchymatous) layer and the third (probably mostly parenchymatous) layer. Drawing: Pollyanna von Knorring.

pylar tube is straight, appears sturdy, and extends out of the seed envelope(s) at a slight angle. It is nearly equal in width throughout its length (Figure $2 \mathrm{~b}$ ); its diameter is about $0.2 \mathrm{~mm}$ proximally and about $0.1 \mathrm{~mm}$ distally. The total length of the micropyle is about 4.5-5.5 $\mathrm{mm}$ and the exposed part about $2.5-3.5 \mathrm{~mm}$. The nucellus is not observed.

\section{Discussion}

Interpretation of the fossil and its systematic position

The vegetative and reproductive features of the new fossil exclude a relationship to any other group than the Gnetales. Ovules surrounded by one or two seed envelopes and with the integument extended into a long exposed micropylar tube are known only for extant and extinct Gnetales, for at least some members of the Bennettitales $[14,18,31]$ and for a number of extinct plants thought to be closely related to Gnetales: i.e., the Erdtmanithecales [33] and a number of unassigned taxa based on dispersed seeds, such as Buarcospermum, Lignierispermum, Lobospermum, Rugonella [14]Raunsgaardispermum [18].

A close relationship with the Bennettitales can be ruled out based on vegetative as well as reproductive characters. The Bennettitales have ovules borne on long stalks, like Siphonospermum simplex, but the Bennettitales are otherwise distinct from Siphonospermum in having ovules borne in densely crowded heads and interspersed with fleshy interseminal scales. The Bennettitales are further distinguished by their typically larger and compound leaves. The Erdtmanithecales are known only from dispersed reproductive structures (seeds, male organs, pollen) [see summary e.g., in [13]]. The seeds of Erdtmanithecales are distinguished by their three-valved seed envelope, but further comparison with Erdtmanithecales is not possible.

Higher level relationship of Siphonospermum simplex (its systematic position within the Gnetales) is more difficult to establish due to the restricted amount of preserved information. Its morphology differs substantially from that of other gnetalean fossils from the Yixian Formation, which have compound cones comprising cone bracts and seeds $[7,11,12]$. They are generally interpreted as close relatives of Ephedra. In contrast, the reproductive units of Siphonospermum consist only of single ovules (with surrounding envelope[s]); there are no supporting bracts.

The long and conspicuous micropylar tubes of Siphonospermum are well preserved and have not been bent or curled during fossilization. Their walls are prominent (Figure 2b) and one tube (Figure 2a, left ovule) is broken at the apical level of the seed envelope. In Ephedra, Gnetum and Welwitschia, the inner epidermis of the micropylar tube is strongly thickened, probably lignified [[34], and pers. obs.], and the same appears to hold for Siphonospermum. Conceivably, the thickening and support for the micropylar tube have been important in the Gnetales in order to withstand visits from pollinators. Nothing is known about the pollination biology of Siphonospermum, 
but in extant Gnetales, pollination drops secreted via the micropylar tube serve as reward for pollinators (mainly Dipterans and Hymenopterans) [35-38]. Abiotic pollination is probably also important, at least in Ephedra $[38,39]$.

Vegetative characters of Siphonospermum simplex are similar to extant Ephedra, with striate, erect stems and linear leaves opposite at nodes and with joined bases. However, these characters are not unique to Ephedra, but are general (ancestral) characters of the Gnetales, at least partly present also in Gnetum, Welwitschia and other gnetalean fossils [e.g., [4,12]]. The venation of the leaves of Siphonospermum is difficult to assess with certainty due to poor preservation and slightly folded leaves. There are three primary veins and perhaps also second order venation. The latter feature is interesting because it is a derived feature within the Gnetales, which characterizes the Gnetum-Welwitschia clade. Extant Ephedra species have two primary veins in leaves and cone bracts and so have most Early Cretaceous ephedroids such as Liaoxia $[12,40]$. One ephedroid fossil, Liaoxia robusta [12], has three or four primary veins but second order venation is unknown in fossil ephedroids as well as in extant Ephedra.

Siphonospermum has several features in common with Gnetum. The "reticulate" venation of Gnetum leaves develops from successive dichotomies in 5-10 parallel veins located in the centre of the leaf [41] and basically, the venation pattern of Siphonospermum is not different from that seen in Gnetum. The reproductive units of Siphonospermum have a similar shape as those of Gnetum and are (like in Gnetum) completely exposed with no remnants of cone bracts. Weak impressions of a structure at the lower left of the reproductive unit with the broken micropylar tube (Figure 2a, arrow 4) are not remains of a bract but reflect the original position of the ovule. This reproductive unit appears to have been detached and slightly displaced.

In Gnetum the nucellus is surrounded by three structures, an integument that forms the extending micropylar tube, a sclerenchymatous inner seed envelope and a second seed envelope, composed of parenchymatous cells and sclereids $[42,43]$. In Siphonospermum, the integument is surrounded by a persistent coalified tissue and its preservation mode indicates that it is sclerenchymatous. In the acuminate apex region, there are weak impressions of an additional tissue. There are no remains of sclerenchymatous tissue in this zone; it has obviously only left an imprint without cellular remains, which suggests soft tissue.

Further, the numerous supportive strands in the sclerenchymatous zone form a pattern with dichotomies and anastomoses, which is very similar to that formed by vascular bundles in the "endotesta" of Gnetum [44]. In the
Gnetales, vascular bundles are absent in the integument but present in the seed envelopes [24], which supports our interpretation that the supportive strands of Siphonospermum are originally derived from the seed envelope.

\section{Conflicting information and uncertain evolutionary relationships}

An evolutionary origin of the spikes of Gnetum, with sessile reproductive units arranged in whorls, from the pedunculate and solitary units of Siphonospermum, could be hypothesized by introducing hypothetical steps. However, there are several noteworthy differences between Siphonospermum and Gnetum, which make evolutionary relationships uncertain. First, the linear leaves and arrangements of the reproductive units are different from those of Gnetum (but likely plesiomorphic features in the Gnetales). Second, in Gnetum the micropylar tube is closed by radially expanding cells of the integument [45], whereas the micropylar tubes of Ephedra and Welwitschia are hollow [28,42] (and pers. obs.). In Siphonospermum, the micropylar tube is isodiametric and there are no indications of a closure tissue. Third, it is not possible to say if the outermost tissue of the reproductive units of Siphonospermum represents an additional seed envelope like in Gnetum [24], or an outer parenchymatous zone of a single seed envelope like in most species of Ephedra [34].

Thus, several seemingly "ephedroid" features of Siphonospermum may instead be plesiomorphic in the Gnetales, and retained in Siphonospermum. The general structure of the reproductive units indicates a sister relationship with Gnetum. If so, the closure tissue in the micropylar tube is a unique feature for Gnetum [and at least some species of Bennettitales [45]], not shared by Siphonospermum (or is missing in Siphonospermum because of an early stage of development). Alternatively, Siphonospermum could be sister to the Gnetum-Welwitschia clade; further studies of the diversity in the Gnetales and related taxa, and a better understanding of character evolution, are needed to elucidate higher level relationships among living and fossil species and the exact phylogenetic position of Siphonospermum simplex.

\section{Conclusions}

The new Early Cretaceous impression/compression fossil described here, Siphonospermum simplex, possesses several key characters that suggest a close relationship with Gnetales and more specifically with the Gnetum-Welwitschia clade. Ovules borne without subtending cone bracts but with a possible second seed envelope indicate a relationship with Gnetum. However, there are also differences between Gnetum and Siphonospermum, most importantly the apparent absence of closure tissue in the micropylar tube. 
Character evolution in the Gnetales and related extinct taxa is not fully understood. Often, a mixture of characters previously thought to be diagnostic for either the Ephedra lineage, the Gnetum-Welwitschia clade, or the Bennettitales, are seen in recently described charcoalified seeds $[14,18]$ and the same is true for the new fossil presented here. Siphonospermum simplex clearly constitutes a new evolutionary lineage within the Gnetales, perhaps sister to Gnetum or to the Gnetum-Welwitschia clade, but its precise systematic position can currently not be resolved with certainty.

\section{Systematics}

\section{Spermatophyta}

\section{Order: Gnetales}

Siphonospermum gen. nov.

Generic diagnosis: Erect stem with terminal units of reproductive structures. Leaves linear, opposite at node, with primary parallel venation. Reproductive units without supporting bracts and terminal on median and lateral branches, narrowly ovoid with rounded base, extended acuminate apex, each consisting of one ovule, orthotropous and unitegmic. Ovules surrounded by an inner sclerenchymatous and an outer parenchymatous layer. Integument extended apically into a long thread-like micropylar tube.

Etymology: From the long thread-like micropyle (siphon) and seed (spermum).

\section{Type species: Siphonospermum simplex sp. nov.}

Specific diagnosis: As for the genus.

Etymology: From the simple architecture of the plant.

Holotype: 9880A (Figure 1a), 9880B (Figure 1b), housed in the palaeobotanical collections of the Institute of Botany, CAS, Beijing.

Stratigraphic position and age: Yixian Formation, Lower Cretaceous, (Early Aptian-early Late Aptian).

Description and comments: See results.

\section{Methods}

The fossil material described here was collected from the Yixian Formation by a local collector and occurs as part and counterpart on a slab of finely laminated light grey to yellowish siltstone. The fossil is preserved as compressions/impressions with only little organic material remaining. No detailed locality information was attached to the specimen, but examination of the lithology suggests that the fossil was collected from the Jianshangou locality (Beipiao, Chaoyang City, west Liaoning) from the lower part of the Yixian Formation (Wang Xiaolin, personal communication 2006). In the present work we leave the exact provenance open and refer broadly to the Yixian Formation of Northeast China.

The Yixian Formation is widely distributed in the western part of the Liaoning Province, but outcrops also in northern Hebei and Inner Mongolia. The age is established by radiometric dating to about $125-120 \mathrm{Ma}$ [see summary in [46]], corresponding to the Early Aptian-earliest Late Aptian [47]. The exceptionally rich fauna and flora are important constituents of the Jehol Biota. The fauna is particularly well preserved and includes a diversity of invertebrates, osteichthyan fish, amphibians, mammals and reptiles including feathered dinosaurs and early birds [48]. The flora is also diverse [7,49], but generally the preservation of the plant fossils is not as good as for the fossil animals. Fossil plants related to Gnetales are particularly diverse $[7,11,12,40]$ (and the new fossil described here). Most gnetalean fossils are ephedroid, but none of them possesses defining characters of extant Ephedra and most of them have been assigned to various species of the extinct genus Liaoxia.

To comply with requirements of the ICBN, we have deposited paper copies of this article at the University of Zürich (library of the Institute of Systematic Botany); Stockholm University (library of the Department of Botany); Peking University Library, Beijing; Chinese Academy of Sciences, Beijing (library of the Institute of Botany); and the Swedish Museum of Natural History (library of the Department of Palaeobotany).

\section{Authors' contributions}

CR and EMF conducted data analyses and evolutionary interpretations. CR wrote the manuscript and EMF provided extensive contributions to the text. All authors read and approved the final manuscript.

\section{Acknowledgements}

The authors thank Duan Shuying (Chinese Academy of Sciences, Beijing) for access to material, Peter Endress (University of Zürich) for valuable comments on the text, Christian Pott (Swedish Museum of Natural History) for assistance with photography and Pollyanna von Knorring (Swedish Museum of Natural History) for preparing the line drawing. The project was supported by grants from the Swedish Research Council and the Asian-Swedish Research Partnership Programme (Swedish Research Council and Swedish International Development Cooperation Agency) to EMF and from the Swedish Research Council and the Royal Swedish Academy of Sciences to CR.

\section{Author Details}

1 University of Zürich, Institute of Systematic Botany, Zollikerstrasse 107, CH8008 Zürich, Switzerland and 2Swedish Museum of Natural History,

Department of Palaeobotany, Box 50007, SE-104 05 Stockholm, Sweden

Received: 7 July 2009 Accepted: 17 June 2010

Published: 17 June 2010

\section{References}

1. Kubitzki K: The families and genera of vascular plants. In Vol I. Pteridophytes and Gymnosperms Berlin: Springer; 1990.

2. Arber EAN, Parkin J: Studies on the evolution of angiosperms: the relationship of the angiosperms to the Gnetales. Ann Bot 1908, 22:489-515

3. Krassilov VA: Early Cretaceous flora of Mongolia. Palaeontographica B 1982, 181(1-3):1-43

4. Crane PR, Upchurch GR: Drewria potomacensis gen. et sp. nov., an Early Cretaceous member of Gnetales from the Potomac Group of Virginia. Am J Bot 1987, 74:1722-1736.

5. Duan S: The oldest angiosperm - a tricarpous female reproductive fossil from western Liaoning Province, NE China. Sci China Ser D 1998, 41(1):14-20 
6. Guo S, Wu X: Ephedrites from latest Jurassic Yixian Formation in western Liaoning, Northeast China. Acta Palaeontol Sin 2000, 39(1):81-91.

7. Sun G, Zheng S, Dilcher DL, Wang Y, Mei S: Early angiosperms and their associated plants from western Liaoning, China. Shanghai: Shanghai Scientific and Technological Education Publishing House; 2001.

8. Rydin C, Mohr B, Friis EM: Cratonia cotyledon gen. et sp. nov.: a unique Cretaceous seedling related to Welwitschia. Biol Letters 2003, 270(S1):29-32.

9. Mohr BAR, Bernardes-de-Oliveira ME, Barreto AMF, Castro-Fernandes MC Gnetophyte preservation and diversity in the Early Cretaceous Crato Formation (Brazil) [abstract]. In VII International Organisation of Palaeobotany Conference Bariloche, Argentina; 2004:81.

10. Dilcher DL, Bernardes-de-Oliveira ME, Pons D, Lott TA: Welwitschiaceae from the Lower Cretaceous of northeastern Brazil. Am J Bot 2005, 92:1294-1310

11. Yang Y, Geng B, Dilcher DL, Chen Z, Lott TA: Morphology and affinities of an Early Cretaceous Ephedra (Ephedraceae) from China. Am J Bot 2005, 92(2):231-241.

12. Rydin C, Wu S, Friis EM: Liaoxia (Gnetales): ephedroids from the Early Cretaceous Yixian Formation in Liaoning, northeastern China. PI Syst Evol 2006, 262:239-265.

13. Rydin C, Pedersen KR, Crane PR, Friis EM: Former diversity of Ephedra (Gnetales): evidence from Early Cretaceous seeds from Portugal and North America. Ann Bot 2006, 98:123-140.

14. Friis EM, Pedersen KR, Crane PR: Early Cretaceous mesofossils from Portugal and eastern North America related to the BennettitalesErdtmanithecales-Gnetales group. Am J Bot 2009, 96(1):252-283.

15. Guo S-X, Sha J-G, Bian L-Z, Qiu YL: Male spike strobiles with Gnetum affinity from the Early Cretaceous in western Liaoning, Northeast China. J Syst Evol 2009, 47(2):93-102.

16. Tao J, Yang Y: Alloephedra xingxuei gen. et sp. nov., an Early Cretaceous member of Ephedraceae from Dalazi Formation in Yanji Basin, Jilin Province of China. Acta Palaeontol Sin 2003, 42:208-215.

17. Krassilov VA: New floral structures from the Lower Cretaceous of Lake Baikal area. Rev Palaeobot Palynol 1986, 47:9-16.

18. Mendes MM, Pais J, Friis EM: Raunsgaardispermum lusitanicum gen. et sp nov., a new seed with in situ pollen from the Early Cretaceous (probably Berriasian) of Portugal: Further support for the Bennettitales-Erdtmanithecales-Gnetales link. Grana 2008, 47(3):211-219

19. Krassilov VA, Bugdaeva EV: Gnetophyte assemblage from the Early Cretaceous of Transbaikalia. Palaeontographica B 2000, 253:139-151.

20. Krassilov VA, Bugdaeva EV: An angiosperm cradle community and new proangiosperm taxa. Acta Palaeobot 1999:111-127.

21. Ash S: Late Triassic plants from the Chinle Formation in north-eastern Arizona. Palaeontology 1972, 15(4):598-618

22. Krassilov VA, Bugdaeva EV: Gnetalean plants from the Jurassic of UstBalej, East Siberia. Rev Palaeobot Palynol 1988, 53:359-374.

23. Eames AJ: Relationships of Ephedrales. Phytomorphology 1952, 2:79-100

24. Takaso T, Bouman F: Ovule and seed ontogeny in Gnetum gnemon L Bot Mag Tokyo 1986, 99:241-266.

25. Crane PR: The fossil history of the Gnetales. Int J PI Sci 1996 , 157(6):S50-S57.

26. Endress PK: Structure and function of female and bisexual organ complexes in Gnetales. Int J PI Sci 1996, 157(6):S113-S125.

27. El-Ghazaly G, Rowley JR, Hesse H: Polarity, aperture condition and germination in pollen grains of Ephedra (Gnetales). PI Syst Evol 1998 213:217-231.

28. Thoday MG, Berridge EM: The anatomy and morphology of the inflorescences and flowers of Ephedra. Ann Bot 1912, 26:953-985.

29. Rydin C, Pedersen KR, Friis EM: On the evolutionary history of Ephedra: Cretaceous fossils and extant molecules. Proc Natl Acad Sci USA 2004, 101(47):16571-16576.

30. Crane PR: Phylogenetic relationships in seed plants. Cladistics 1985, 1:329-348.

31. Friis EM, Crane PR, Pedersen KR, Bengtson S, Donoghue PCJ, Grimm GW, Stampanoni M: Phase-contrast X-ray microtomography links Cretaceous seeds with Gnetales and Bennettitales. Nature 2007. 450(7169):549-552
32. Rothwell GW, Crepet WL, Stockey RA: Is the anthophyte hypothesis alive and well? New evidence from the reproductive structures of Bennettitales. Am J Bot 2009, 96(1):296-322.

33. Pedersen KR, Crane PR, Friis EM: Pollen organs and seeds with Eucommiidites pollen. Grana 1989, 28:279-294.

34. Rydin C, Khodabandeh A, Endress PK: The female reproductive unit of Ephedra (Gnetales): comparative morphology and evolutionary perspectives. Bot J Linn Soc, in press.

35. Wetschnig W, Depisch B: Pollination biology of Welwitschia mirabilis Hook.f. (Welwitschiaceae, Gnetopsida). Phyton 1999, 39(1):167-183.

36. Kato M, Inoue T, Nagamitsu T: Pollination biology of Gnetum (Gnetaceae) in a lowland mixed dipterocarp forest in Sarawak. Am J Bot 1995, 82(7):862-868.

37. Porsch O: Ephedra campylopoda C.A.Mey., eine entomophile Gymnosperme. Ber Deut Bot Ges 1910, 28(8):404-412.

38. Meeuse ADJ, DeMeijer AH, Mohr OWP, Wellinga SM: Entomophily in the dioecious gymnosperm Ephedra aphylla Forsk. (=E. alte C.A.Mey.), with some notes on Ephedra campylopoda C.A.Mey. III. Further anthecological studies and relative importance of entomophily. Israe/ J Bot 1990, 39:113-123.

39. Niklas KJ, Buchmann SL: Aerodynamics of pollen capture in two sympatric Ephedra species. Evolution 1987, 41:104-123.

40. Cao Z, Wu S, Zhang P, Li J: Discovery of fossil monocotyledons from Yixian Formation, western Liaoning. Chinese Sci Bull 1998, 43(3):230-233

41. Rodin RJ: Ontogeny of foliage leaves in Gnetum. Phytomorphology 1967, 17:118-128.

42. Pearson HHW: Gnetales. Cambridge: Cambridge University Press; 1929.

43. Thoday MG: Anatomy of the ovule and seed in Gnetum gnemon, with notes on Gnetum funiculare. Ann Bot 1921, 35:37-53.

44. Rodin RJ, Kapil RN: Comparative anatomy of the seed coats of Gnetum and their probable evolution. Am J Bot 1969, 56:420-431.

45. Berridge $\mathrm{EM}$ : On some points of resemblance between gnetalean and bennettitean seeds. New Phytol 1911, 10:140-144.

46. Zhou Z: Evolutionary radiation of the Jehol Biota: chronological and ecological perspectives. Geol J 2006, 41(3-4):377-393.

47. Gradstein FM, Ogg JG, Smith AG: A Geologic Time Scale. Cambridge: Cambridge University Press; 2004

48. Chang M, Chen P, Wang Y, Wang Y, Mioa D: The Jehol Biota. Shanghai: Shanghai Scientific \& Technical Publishers; 2003.

49. Wu S: A preliminary study of the Jehol flora from western Liaoning. Palaeoworld 1999, 11:7-37. (in Chinese with English summary)

doi: 10.1186/1471-2148-10-183

Cite this article as: Rydin and Friis, A new Early Cretaceous relative of Gnetales: Siphonospermum simplex gen. et sp. nov. from the Yixian Formation of Northeast China BMC Evolutionary Biology 2010, 10:183

\section{Submit your next manuscript to BioMed Central and take full advantage of:}

- Convenient online submission

- Thorough peer review

- No space constraints or color figure charges

- Immediate publication on acceptance

- Inclusion in PubMed, CAS, Scopus and Google Scholar

- Research which is freely available for redistribution 